\title{
Acquired vaginal stenosis following caesarean delivery: a case report
}

\section{Chandana Ray Das*, Alakananda, Rakhi Bora, Bonani Das}

Department of Obstetrics and Gynecology, Gauhati Medical College, Guwahati, Assam, India

Received: 23 August 2017

Revised: 09 September 2017

Accepted: 16 September 2017

\section{* Correspondence:}

Dr. Chandana Ray Das,

E-mail: chandanaraydas@yahoo.in

Copyright: (c) the author(s), publisher and licensee Medip Academy. This is an open-access article distributed under the terms of the Creative Commons Attribution Non-Commercial License, which permits unrestricted non-commercial use, distribution, and reproduction in any medium, provided the original work is properly cited.

\begin{abstract}
Postpartum genital tract adhesions are infrequent and their reason has not been appraised. Though, severe dystocia and frequent pelvic examinations have been projected as possible causes. Here, we report a case of vaginal adhesions following caesarean section for obstructed labour that presented as irregular menstruation with desire to remove the PPIUCD. The patient was successfully treated with surgical resection.
\end{abstract}

Keywords: Adhesion, Infection, Stenosis, Vagina

\section{INTRODUCTION}

Acquired vaginal stenosis is rarely seen in the present era. In the past, in some countries, acquired gynaetresia (vaginal stenosis) was a known entity due to certain cultural practices. In a Nigerian study the incidence was 7$8.5 / 1000$ in Nigeria and peak age was $20-30$ years. ${ }^{1}$

Chemical vaginitis resulting from insertion of caustic vaginal pessaries, secondary to local herb pessary insertion, and female circumcision was the most common cause for acquired gynaetresia mostly found in Nigeria. ${ }^{2}$

Labial adhesions or an actual adhesion of the vaginal cavity in reproductive aged women are known to be rare though several cases of labial adhesions in postpartum women have been reported but no cases of vaginal adhesion at the level of mid vagina following caesarean delivery has been reported. ${ }^{3,4} \mathrm{We}$ are presenting this rare case of vaginal adhesion following caesarean delivery.

\section{CASE REPORT}

20 year old lady came with scanty menstruation following caesarean section and also wants to remove CU-T. Her immediate past obstetrics history suggest that the patient was undergone emergency LSCS 5 month back for the diagnosis of primigravida at term pregnancy with pregnancy induced hypertension (PIH) with obstructed labour.

Intraoperative finding was bladder oedematous, lower segment distended, liquor was thickly meconium stained. A stillborn baby was delivered by Patwardhan technique. PPIUCD was inserted and abdomen was closed in layers. Postoperatively catheter was kept in situ for 14days. She had wound infection and gapping for which secondary suturing was done. She was discharged after 19 days of hospital stay with advice for check-up after 6weeks, but she did not turn up for follow up.

On per speculum examination vagina was normal in the lower part which ended blindly with a pin hole opening towards right.

Per vaginal examination cervix was not felt, vagina sealed in the upper part. Per rectal examination uterus was normal in size. On ultrasonography uterus was retroverted, CU-T in situ, cervical canal patent, uterine scar healthy. 
Diagnosis was secondary vaginal stenosis with CU-T in situ.

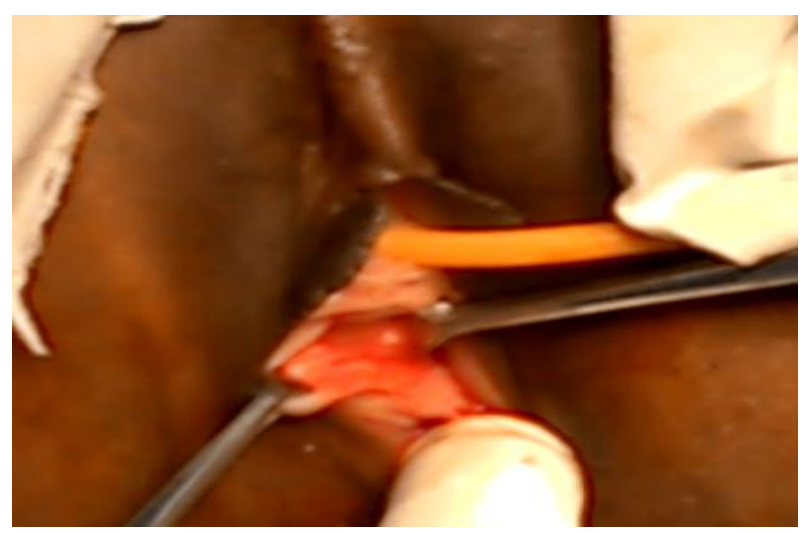

Figure 1: Vaginal stenosis.

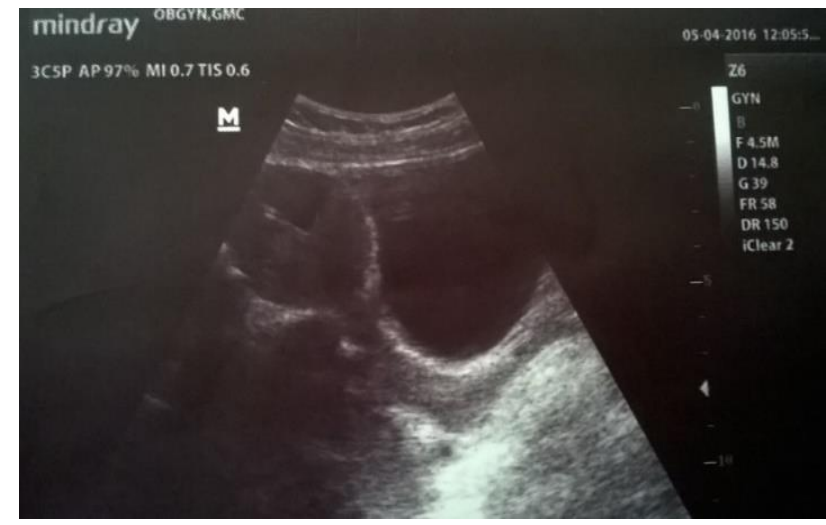

Figure 2: USG showing CU-T with patent cervix.

Management - Pinhole opening was dilated and dense vaginal adhesion was released gradually till the cervix and the CU-T thread was visualised. Cervix was found to be normal. CU-T was removed and vaginal mould was applied.

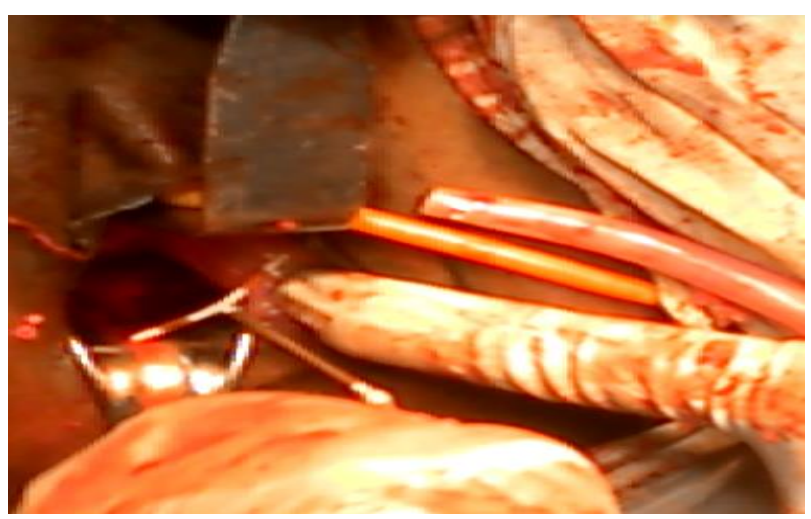

Figure 3: Removed CU-T.

\section{DISCUSSION}

Postpartum genital tract adhesions are unfamiliar, and their reason has not been appraised properly. However, numerous pelvic examinations have been suggested as possible causes. Previous reports showed that genital tract trauma such as large vulvar oedema, or vaginal or labial laceration is associated with postpartum labial adhesions. $^{3,5}$ Strangely, our case presented as actual obstruction of the vaginal canal. Kamal et al in 2010 presents a case of pinhole vagina following vaginal delivery. ${ }^{6}$ Postpartum vaginal adhesion after spontaneous delivery is rare and the present case highpoints a thoughtprovoking complication of caesarean delivery in a hypoestrogenic stat. ${ }^{7}$

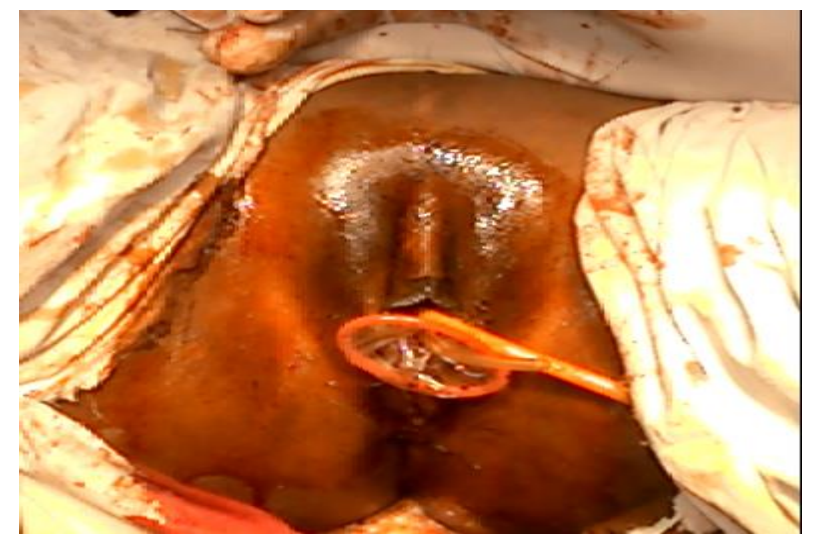

Figure 4: Vaginal reconstruction operation.

In present case the vaginal adhesion might have been due to fibrotic tissues forming adhesion. The patient was being referred late with obstructed labour in second stage of labour and this excludes congenital adhesion of vagina.

Subsequently she underwent caesarean section and baby was delivered by Patwardhan technique. In our case two possibilities of formation of vaginal adhesion, one is numerous pelvic examinations leading to vaginal laceration and infection. During the healing process after this trauma, fibrotic tissues formed adhesion in her vaginal canal.

Second one is undiagnosed laparoelytrotomy (delivery of a baby through vaginal incision in caesarean section) and accidental inclusion of posterior vaginal wall during repair. ${ }^{8}$ However, this was not an ideal case for PPIUCD insertion as presence of infection is a contraindication.

Surgery is required in postpartum vaginal stenosis because of its dense nature. Simple incision of the fibrous bands of tissue causing adhesion is sufficient enough to restore the normal anatomy. If there is extensive tissue damage then various technique of vaginoplasty can be employed. ${ }^{9}$

\section{CONCLUSION}

We hope that present case will increase awareness about postpartum genital tract adhesions. Fully trained delivery assistance is very essential for conducting a delivery and optimum management can prevent such complications. We might also mention that obstetricians evade numerous 
pelvic examinations and trauma to the genital tract in an attempt to prevent postpartum genital tract adhesions. While doing caesarean section in obstructed labour one should be careful enough to avoid laparoelytrotomy as well as during repair if it occurs.

Funding: No funding sources

Conflict of interest: None declared

Ethical approval: Not required

\section{REFERENCES}

1. Arowojolu AO, Okunlola MA, Adekunle AO, Ilesanmi AO. Three decades of acquired gynaetresia in Ibadan: clinical presentation and management. J Obstet Gynecol. 2001 Jul;21(4):375-8.

2. Ugburo AO, Fadeyibi IO, Oluwole AA, Mofikoya BO, Gbadegesin A, Adegbola O. The epidemiology and management of gynatresia in Lagos, southwest Nigeria. Int $\mathbf{J}$ Gynecol Obstet. 2012 Sep 30;118(3):231-5.

3. Seehusen DA, Earwood JS. Postpartum labial adhesions. J Am Board Fam Med. 2007 Jul 1;20(4):408-10.
4. Sharma B, Arora R, Preston J. Postpartum labial adhesions following normal vaginal delivery. J Obstet Gynecol. 2005;25:215.

5. Kim HM, Bae JY, Cho YJ, Kim MJ, Cha HW, Seong WJ. Vaginal adhesions in a woman with the history of dystocia. Obstet Gynecol Sci. 2014;57(2):180.

6. Zahran KM, Eldin WS. Pinhole Vagina Following Mismanaged Vaginal Delivery. J Gynecol Surg. 2010 Dec 1;26(4):267-70.

7. Graziottin A. Iatrogenic and post-traumatic female sexual disorder. Sexual Medicine S. 2006:351.

8. Rashid M, Rashid M. Accidental delivery of a baby during a caesarean section through a vaginal incision (a laparoelytrotomy). BMJ case reports. 2010 Jan 1;2010:bcr0720103135.

9. Rathod S, Samal SK. Secondary vaginal atresia treated with vaginoplasty using amnion graft: a case report. J Clin Diagn Res. 2014 Nov;8(11):OD05-6.

Cite this article as: Das CR, Alakananda, Bora R, Das B. Acquired vaginal stenosis following caesarean delivery: a case report. Int J Reprod Contracept Obstet Gynecol 2017;6:5158-60. 